\title{
Description of development of prosumer energy sector in Poland
}

ABSTRACT: The primary aim of this paper was to assess the development of prosumer energy sector in Poland. In the first point, the basic notions connected with prosumer energy (micro-installation, prosumer) were discussed on the basis of Law of Renewable Energy Sources of February 20, 2015 (Journal of Laws, item 478, as amended) and the main aspects of the European Union energy policy where presented in the context of the development of the prosumer energy sector. In this part of the study, numerous benefits for the Polish economy and consumers of electrical energy, connected with the expansion of prosumer energy sector, were presented. On the other hand, many obstacles which stall this sector in Poland were noticed. In the second point the most important regulations from the Law of Renewable Energy Sources of February 20, 2015 were analyzed (In the second point the most important regulations from the Law of Renewable Energy Sources of February 20, 2015 (hereinafter: the RES act) were analyzed). On the basis of this legal act, the so called "rebate system", which is currently used in Poland to support prosumers of electrical energy, was described. Moreover, many legal and administrative simplifications implemented by the RES act were indicated. The analytical approach to the RES Act in this study resulted in the detection of many regulations in this legal act which may have an adverse impact on the development of the prosumer energy sector in Poland. In the third point, programs co-financed by the Polish government or the European Union, which financially support the purchase and installation of energy technologies using RES, were described. Statistical data connected with the prosumer energy sector in Poland was presented in the fourth point of this paper. On the basis thereof, the authors attempted to find the correlation between the number of prosumers and the share of the amount of electrical energy from renewable

\footnotetext{
1 AGH University of Science and Technology in Kraków, Faculty of Energy and Fules, Department of Thermal and Fluid Flow Machines; e-mail: kuchmacz@agh.edu.pl; e-mail: jankuchmacz7@gmail.com,1mika@agh.edu.pl
} 
energy sources in gross electrical energy consumption. In the fifth point issues connected with energy technologies used in the Polish prosumer energy sector were discussed. Moreover, this point focuses on the great popularity of photovoltaic modules among Polish prosumers and results in the reluctance of Polish prosumers to install wind microturbines and small hydroelectric power plants.

KEYWORDS: prosumer energy, renewable energy, the RES Act

\section{Introduction}

At the end of the nineteenth century, the rapid development of electrotechnics took place. The first local power grids supplying electrical energy to a small number of households were developed. Low power plants produced electrical energy that was sent over the local power grid to receivers at a short distance. In the twentieth century, the increase in the demand for electrical energy, along with the development of energy technologies, triggered the emergence of national power grids, in which the production of electrical energy takes place in power plants with the power expressed in gigawatts. The cooperation of many high power plants within the power system undoubtedly improves the security of energy supplies to its users. However, it should be noted that system power plants powered by fossil fuels cause pollution of the natural environment, which is now a widely discussed problem.

Thanks to the development of energy technologies which allow for the use of renewable energy sources (RES), electrical energy may again be produced and used locally. The energy user has the option of installing, for example, photovoltaic panels on its site which will cover part or all of his electrical energy demand. In the event of the overproduction, unused electrical energy may be transferred to the electrical energy grid. In the situation described above, we are dealing with prosumption. The end user of electrical energy has ceased to only be its consumer, but he has also become a producer.

The purpose of this paper is to characterize the state of prosumer energy development in Poland. The paper discusses the potential benefits of the prosumer energy model and the numerous problems that stand in the way of its dynamization. The next issue looked into were the legal regulations governing prosumer energy in Poland, which result from the Act on Renewable Energy Sources of February 20, 2015 (Journal of Laws, item 478). Particular attention was paid to the numerical data allowing to assess the state of prosumer energy development in Poland. The work also describes particular energy technologies and the reason of their use by the Polish prosumers. 


\section{Prosumer energy - a source of ideas, notions, benefits and barriers}

The use of non-renewable resources for energy production is looked at more and more critically because of the intention to limit the health and environmental effects of such energy conversion (Burchard-Dziubińska 2015). The development of prosumer energy in the European Union results from its energy policy consisting in the pursuit of using renewable energy sources on the widest possible scale by the Community members. It should be mentioned here that Directive 2009/28/EC of April 23, 2009, which obliges the European Community, among others, to obtain a $20 \%$ share of energy from RES in the final gross energy consumption by 2020 (OJ L 140 of 2009, p. 16). The requirements were set individually for each EU country, whereby the target for Poland has been to increase the share of energy from RES to $15 \%$. The assumptions of the energy policy conducted by the European Community are not going to change in the upcoming years, which has been evidenced by a communication of the European Commission on the climate and energy framework for the years 2020-2030, the aim of which is, among others, obtaining at least a $27 \%$ share of energy from RES in the total energy consumption (Communication... 2014). Completing the EU targets will only be possible with the active participation of prosumers who, producing energy in the systems using RES, will contribute to major changes in the energy production structure (the so-called energy mix) of individual countries. The strongest confirmation of the above thesis is the fact that in $2012,46 \%$ of the installed RES power in Germany belonged to prosumers (Bajczuk 2014).

Key notions related to prosumer energy are microinstallation and microgeneration. Microgeneration is the production of electrical energy or heat in low-power generation units using energy technologies which employ renewable energy or low-emission energy technologies. Microgenerators are connected to a low voltage network, with a rated current not exceeding 16A (PN-EN 50438: 2010 ... 2010). The definition of microinstallation is included in the Act on Renewable Energy Sources of February 20, 2015, according to which a microinstallation is a renewable energy installation with a total installed electric power not more than $40 \mathrm{~kW}$, connected to a power grid with a rated voltage lower than $110 \mathrm{kV}$ or power heat achievable in combination with no more than $120 \mathrm{~kW}$ (Journal of Laws, item 478, amended). It should be noted that the notions presented above are not synonymous, as the term micro-installation covers only technologies which use renewable energy.

The Act amending the Act on Renewable Energy Sources and some other acts of 22 June 2016 introduced the notion of a prosumer, assigning the following definition to it: a prosumer is a final consumer purchasing electrical energy on the basis of a comprehensive contract, producing electrical energy only from renewable energy sources in micro-installations for own consumption, not related to the economic activity regulated by the Act of July 2, 2004 on the Freedom of Economic Activity (Journal of Laws, item 478, amended). One should pay attention to the fact that the act on RES narrows down the notion of a prosumer to an electrical energy 
producer, which meets the requirements set out in the above definition, and thus deprives support for thermal energy producers in micro-installations.

The successful prosumer energy model appears to be the right answer to the aforementioned requirements related to the share of RES in the energy mix and also brings about a number of ecological, economic, and social benefits. The increase in the number of microinstallations may be one of the solutions to the problem of excessive greenhouse gas emissions. Electrical energy produced using those may still partially replace electrical energy produced in Poland in almost 90\% in high-emission fossil fuel power plants (Słupik 2014). Another advantage of the development of prosumer energy at the state level is undoubtedly the increase in the level of energy security, which results from the increased diversification of energy sources, but also form their dispersion across the country. Just as the positive impact of prosumer energy on the economy important through the creation of new jobs and development of new energy technologies. The advantages of such energy industry model may be attributed mainly to the prosumer itself, whose decision to invest in the purchase and assembly of micro-installations is prompted by rising electrical energy prices. Decreasing energy bills causes a decrease in the cost of maintaining a household and the growing awareness in the society of using new ecological energy technologies is a source of social approval for persons becoming prosumers. The decision to become a prosumer may also be prompted by the decrease in the prices of the micro-installation, which results from the so-called effect of scale and the growing technological maturity of the micro-installation, manifested by the higher efficiency of energy conversion. Prosumer energy is also beneficial for entrepreneurs and farmers. The first of them may, thanks to investments in microinstallations, reduce production costs by lowering electrical energy costs, become more competitive on the market and be able to reduce the company's business risk giving it at least partial independence from the fluctuation of electrical energy prices (Bukowski et al. ed 2014). In turn, farmers may be interested in their own production of electrical energy due to the growing demand, which is a result of the mechanization and automation of agricultural production. Agricultural communes also have the option of using waste biomass in the gasification process. The biogas produced in this process may be used in CHP microgenerators.

Prosumer energy means a historical change in the balance of power in the energy sector by moving away from large-scale corporate energy to dispersed energy generated by an active consumer (Popczyk 2014). The development of the prosumer energy model in Poland, however, requires specific actions in the following areas: legislation, technology, logistics, information, and financing (Rączka et al. ed. 2012). By 2015, the most important barrier blocking the development of prosumer energy in our country was the lack of appropriate legal provisions. This is evidenced by data from reports of the electrical energy distribution system operators included in the report of the Polish Association of Energy Transmission and Distribution with regard to 2015 , according to which only in 2015 , the number of prosumers connected to the grid amounted to 3153, while at the end of 2014 there were only 1585 (Power... 2015). The adoption of the Act on RES on February 20, 2015 led to regulating of the functioning of prosumer energy. However, one should bear in mind that the adoption of an appropriate legal act does not result in arousing interest in prosumption if its provisions are not encouraging prosumers by, for example, limiting 
the red tape or implementing a favorable support system. This issue is discussed in more detail in the next section of this paper. Progress in the field of energy technologies using RES remains undisputed, however, one needs to bear in mind that the stream of investment funds allocated for micro-installations should be located mainly in Poland (Rączka et al. ed. 2012). The development of the national industry producing RES installations will not only increase their quality and efficiency, but also reduce costs, which will be an additional incentive for prosumers. Actions also need to be taken in the area of logistics. This should be understood as the proper organization of, above all, exploitation, consisting in controlling the operation of hybrid energy microsystems, but also the organization of their sale, assembly, and service (Raczka et al. ed. 2012). It is also very important to provide citizens with useful information on prosumer energy. The fact that many of them have poor knowledge about the possibilities of using modern energy technologies and the procedure of becoming a prosumer may not be sufficiently comprehensible for them is worth remembering. The subsidiarity of the state, which should educate citizens in this respect through for example social campaigns, is extremely important in solving these issues. A significant barrier blocking the development of the prosumer energy model are also capital constraints. They mainly concern households and small and medium-sized enterprises that are unable to cover the high costs associated with the purchase and installation of micro-instruments (Stupik 2014). The answer to this issue should be the financial support for prosumers described in the third section of this paper.

\section{Prosumer energy in Poland - legal regulations}

The development of prosumer energy is not possible without the adoption of appropriate legal acts setting out the framework for its functioning. The Act on Renewable Energy Sources, adopted on February 20, 2015, was adopted far too late and from the beginning aroused numerous controversies, which may be borne out by the fact that so far (as of March 2018) the Polish parliament has already adopted eight amendments to the act.

From the point of view of a potential prosumer, the most important issues contained in the Act on RES are the support system and administrative and legal streamlining practices. The version of the Act of February 20, 2015 which included a provision introducing feed in tariffs for prosumers, which were to take effect from 1 January 2016 was considered (Journal of Laws, item 478). The feed in tariffs are tariffs dedicated to individual energy technologies, applied by the investors to sales of energy from RES to the grid within 10-20 years (Wiśniewski 2015). In Poland, a fifteen-year validity period for the tariffs has been adopted. In the case of micro-installations with installed capacity up to $3 \mathrm{~kW}$, a guaranteed price for sales of $75 \mathrm{gr} / \mathrm{kWh}$ has been introduced, and for microinstallations with installed capacity from 3 to $10 \mathrm{~kW}$, the guaranteed price for sales was expected to range from 45 to $70 \mathrm{gr} / \mathrm{kWh}$ depending on the conversion technology (Journal of Laws, item 478). Such a prosumer support system is the dominant system 
in the EU (Żmijewski 2013). However, the Act of December 29, 2015 Amending the Act on Renewable Energy Sources and the Energy Law Act deferred the date of the introduction of the guaranteed tariffs until July 1, 2016 (Journal of Laws, item 2365). On June 22, 2016, however, the Act Amending the Act on Renewable Energy Sources and Some Other Acts which replaced the system of feed in tariffs with the rebate system (Journal of Laws, item 925, hereinafter: amendment to the Act on Renewable Energy Sources of June 22, 2016). The value of the rebate rate is 1:0.7 for all microinstallations with the exception of microinstallations with an installed electric capacity of not more than $10 \mathrm{~kW}$, for which the value of the rebate rate is 1:0.8 (Journal of Laws, item 478, as amended). In this solution, the grid becomes an energy storage site, from which the prosumer may uses a maximum of $70 \%$ or $80 \%$ of energy depending on the electrical power of its micro-installation. For example, a prosumer who is the owner of a micro-installation with $10 \mathrm{~kW}$ of electrical power, who produced $20 \mathrm{kWh}$ of electrical energy, out of which $10 \mathrm{kWh}$ of electrical energy was used for own purposes and $10 \mathrm{kWh}$ was transferred to the grid, may use $8 \mathrm{kWh}$ of electrical energy free of charge for a maximum of one year from the moment of making the energy settlement. In the discussed example, the prosumer gives $2 \mathrm{kWh}$ electrical energy to the seller free of charge. The amendment to the Act on RES of June 22, 2016 prevented prosumers from selling unused electrical energy, as the same time depriving them of the profit on such a sale. Such a solution is criticized by prosumers due to the fact that the savings resulting from the production of electrical energy in their own micro-installation and the consumption of this energy for their own needs are small in comparison with the investment outlays, which results in a long period of return on such an investment.

The Act on RES implements significant administrative and legal streamlining practices for prosumers. The first simplification is the exemption of the prosumer from the obligation to register a business under Article 4(8). A prosumer is not obliged to pay social health insurance contributions, which gives financial savings. It should be noted here that in accordance with Article 4(9) of the Act on RES, the introduction of electrical energy to the grid by prosumers and the collection of this energy from the grid are not services or sales within the meaning of the Act of March 11, 2004 on Tax on Goods and services (Journal of Laws, item 478, as amended). Pursuant to Article 4(10), electrical energy used by the prosumer for its own needs is subject to excise duty. An important simplification introduced by the Act on RES is the fact that the owner of micro-installations no longer needs to have a license for the production of electrical energy, thanks to which it is exempted from an expensive and complicated administrative procedure (Błażejowska 2015). According to Article 5(1), the connection of micro-installations to the grid is carried out by informing of this fact, no later than 30 days prior to making this connection, the electrical energy distribution system operator with data on: type of renewable energy used in this micro-installation, the date of connection of the micro-installation, its location, and installed electrical energy (Journal of Laws, item 478, as amended).

Certain streamlining practices for prosumers were also introduced by changes in the building law and energy law. Pursuant to Article 29(2)(16) of the Building Law, a building permit is not required in the case of construction works involving: assembly of heat pumps, photovoltaic devices with installed electrical power of up to $40 \mathrm{~kW}$, and free-standing solar collectors (Journal 
of Laws, item 414, as amended). Pursuant to Article 7(8) of the Energy Law, no fee is charged for connecting micro-installations to the electrical energy distribution network (Journal of Laws, item 348, as amended).

The definition of prosumer is an issue in the analyzed Act on Renewable Energy. According to the definition presented in the first section of this paper, a person who runs a business and at the same time is a producer of electrical energy in a micro-installation, which they use for purposes not related to economic activity, is a prosumer. This solution creates a problematic situation for persons who have their company's headquarters in their own household. If such persons have installed, for example, a microwind turbine on their premises and are interested in becoming a prosumer within the meaning of the Act on RES, they may only use electrical energy for the needs of their business when the micro-turbine does not produce electrical energy. One should therefore consider developing a new definition of a prosumer which would entitle it to consume electrical energy for business purposes, which would help to avoid similar bizarre situations.

An important problem in the discussed Act on RES is also the unfavorable situation of entrepreneurs who produce electrical energy in micro-installations and are focused on its autoconsumption. According to the provisions of the Act on RES, the version of February 20, 2015, pursuant to Article 41(14), an entrepreneur would have to settle the difference between the amount of electrical energy taken from the grid and the amount of electrical energy contributed to the grid to the seller obliged under the contract for the sale of electrical energy (Journal of Laws, item 478). Such settlements, termed net-metering, should be made in semi-annual periods. In the introduced amendment to the Act on RES of June 22, 2016, this provision was, however, repealed. This results in the fact that entrepreneurs producing electrical energy in micro-installations may sell electrical energy not used for their own needs at a price of $100 \%$ of the average electrical energy sales price on the competitive market in the previous quarter, announced by the President of the Energy Regulatory Office (Journal of Laws, item 478, as amended). It should be stated that such legal status is illogical in the context of the fact that the amendment to the Act on RES of June 22, 2016 was to promote RES installations focused on auto-consumption. Meanwhile, entrepreneurs who have such installations, may only rely on the sale of unused electrical energy at a price of just around PLN 160-170/ MWh (as of 03.2018), while entrepreneurs with RES installations with more power, interested only in the sale of electrical energy, may receive support resulting from the auction system.

\section{Financial aid for prosumers in Poland}

Prosumers may currently rely on the support resulting from the provisions of the Act on RES within the framework of the rebate system discussed in the second item. The persons intending to become prosumers may also apply for co-financing under the Prosumer program or participate in the so-called umbrella program implemented under regional operational programs. 
The purpose of the Prosumer National Fund for Environmental Protection and Water Management program is to reduce or avoid $\mathrm{CO}_{2}$ emissions as a result of increased production of energy from renewable sources (Program... 2016). The program beneficiaries receive funding for the purchase and assembly of new installations and microinstallations of renewable energy sources for the production of electrical energy or heat for the needs of single-family or multi-family housing, including replacement of existing installations with more efficient and environmentally friendly ones (Program... 2016). It is worth noting that support is also provided for micro-installations producing heat, while the Act on RES covers only micro-installations generating electrical energy. The Prosumer program offers financing for installations for the production of electrical energy or heat, which use biomass heat sources, heat pumps. and solar collectors with installed thermal power up to $300 \mathrm{kWt}$ and solar systems, small wind farms, and micro-cogeneration systems with installed electrical power up to $40 \mathrm{kWe}$ (Program... 2016). It should be stated that this co-financing program contributes favourably to the development of prosumer energy in Poland, as evidenced by the increase in the number of microinstallations in 2015-2016 from 4,738 at the end of 2015 to 16,111 at the end of 2016 (Power... 2016).

Only the local government units, their unions and associations may be beneficiaries of umbrella programs (Regionalny... 2014). They obtain subsidies which are used to cover part of the expenses associated with the purchase and installation of RES micro-installations in buildings owned by inhabitants of a given municipality. The subsidy is obtained through a competition-type procedure. Next, the purchased micro-installation, remaining the property of the municipality for the following 5 years, is installed on the property belonging to the inhabitants of this municipality. The energy generated in the micro-installation should be consumed for own household needs, and only its unused part may be introduced into the external grid (Regionalny... 2014). Co-financing may be up to $85 \%$ of eligible expenses. The remaining part should be covered by either the final recipient (the installation user) or the municipality, or such entities jointly participate in expenditures. Umbrella programs should contribute to a significant increase in the number of microinstallations in Poland. According to gramwzielone.pl, the industry portal there will be ten thousand more prosumers in the Podkarpackie Province, thanks to the latest umbrella project competition.

\section{Prosumer energy in Poland - numerical data}

The development of prosumer energy is closely related to the development of RES. This is due to the fact that prosumers using microinstallations contribute to the increase of power capacity installed in RES, and at the same time the development of energy technologies using renewable sources results in the increased interest among potential prosumers. On the basis of Eurostat statistics, the share of energy from RES in Poland in final energy consumption at the end of 2016 was $11.3 \%$, which raises serious doubts about the chance of Poland achieving 
a $15 \%$ share of energy from RES (Eurostat... 2016). Data showing the share of energy from RES in the final energy consumption in the years 2010-2016 in Poland and the European Union are presented in Figure 1.

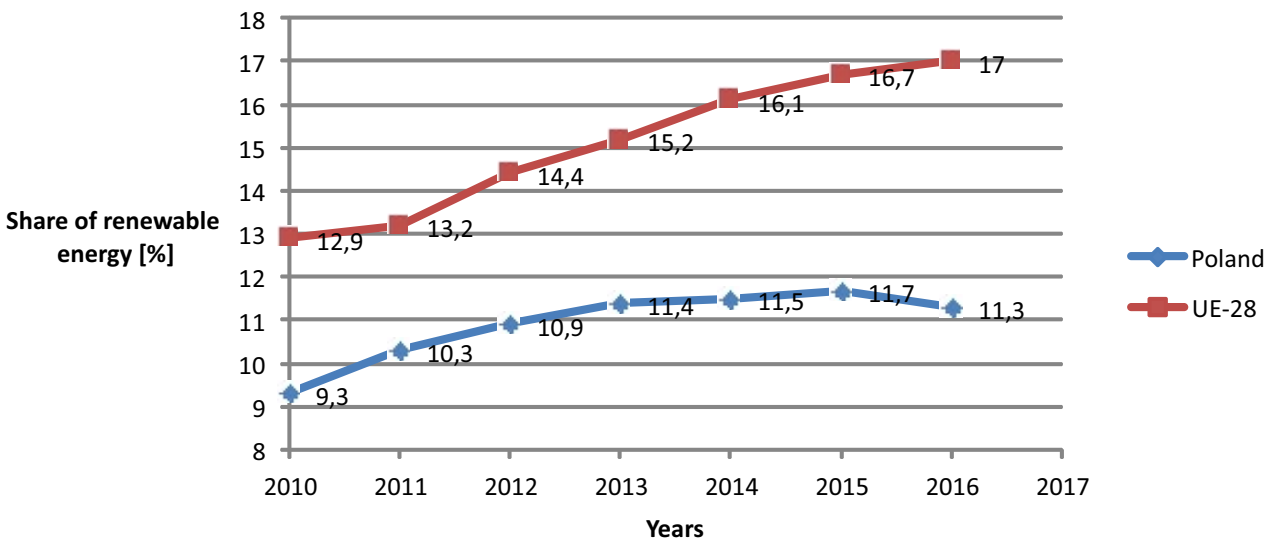

Fig. 1. Share of renewable energy from renewable energy sources in gross final energy consumption over the years 2010-2016

Source: own source on the basis of the Eurostat data

Rys. 1. Udział energii z OZE w końcowym zużyciu energii na przestrzeni lat 2010-2016

A similar trend is observed with respect to the share of electrical energy from RES in its total consumption in Poland and the EU (Fig. 2). The share of green electrical energy in Poland has been growing incrementally, although in the years 2015-2016 manifestations of stagnation in this area were observable.

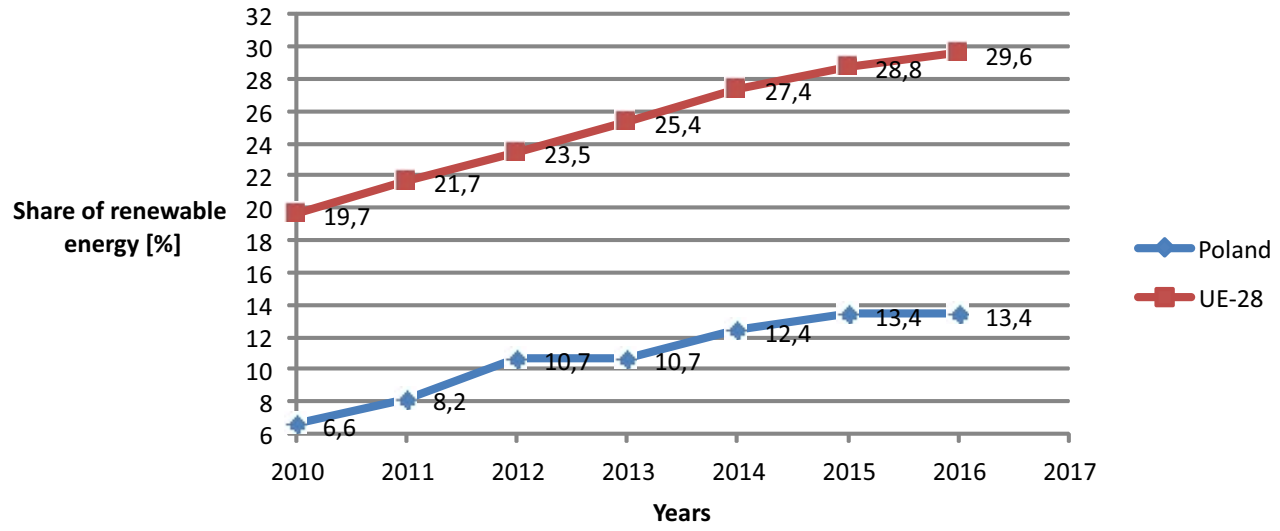

Fig. 2. Share of electrical energy from renewable energy sources in gross electrical energy consumption over the years 2010-2016

Source: own source on the basis of the Eurostat data

Rys. 2. Udział energii elektrycznej z OZE w całkowitym zużyciu energii elektrycznej na przestrzeni lat 2010-2016 
According to the data presented in the reports from 2015 and 2016 of the Polish Society for Transmission and the Distribution of Electrical Energy, one may conclude that the number of prosumers joined to the distribution grid operator in Poland is systematically growing (Table 1). In 2016, most prosumers were connected to the PGE Dystrybucja SA grid operator, which covers the areas of Central and Eastern Poland. There is also a significant increase in the number of prosumers in the south-western part of Poland where the grid operator is Tauron Dystrybucja SA.

TABLE 1. Number of prosumers connected to the grid managed by each operator

TABELA 1. Liczba prosumentów przyłączonych do poszczególnych OSD

\begin{tabular}{|l|r|r|r|r|}
\hline \multicolumn{1}{|c|}{ Grid operator } & 2015 & $\begin{array}{c}\text { Total after } \\
2015\end{array}$ & 2016 & $\begin{array}{c}\text { Total after } \\
2016\end{array}$ \\
\hline Enea Operator & 354 & 516 & 1,912 & 2,428 \\
\hline Energa Operator & 749 & 1,775 & 1,452 & 3,227 \\
\hline PGE Dystrybucja & 1,088 & 1,163 & 4,103 & 5,266 \\
\hline Innogy Stoen Operator & 26 & 41 & 107 & 148 \\
\hline Tauron Dystrybucja & 936 & 1,243 & 3,799 & 5,042 \\
\hline Total & 3,153 & 4,738 & 11,373 & 16,111 \\
\hline
\end{tabular}

Source: own source on the basis of (Power... 2015) and (Power... 2016).

When confronting the above data on the increase in the number of prosumers in 2015-2016 with data on the share of electricity from RES in its total consumption, one may conclude that the increase in the number of prosumers, and hence the increase in the number of microinstallations, did not translate into an increase in green electricity in its total consumption in Poland. However, when considering this issue more broadly, it should be noted that microinstallations, whose total installed electric power amounted only to $91.29 \mathrm{MW}$ at the end of 2016, will not significantly change the share of electrical energy from RES in its total consumption (Power... 2016). The fact that the number of prosumers in Poland, which at the end of 2016 amounted to 16,111, and hence the number of microinstallations, is small worth bearing in mind. The situation is different in Germany, where the number of prosumers exceeded 2 million and they were in possession of RES installations with a total installed electric power of over $16 \mathrm{GW}$ already in 2012 (Bajczuk 2014). Prosumers will therefore play their important role in the development of renewable energy, provided that their number grows. 


\section{Energy technologies used by the Polish prosumers}

Having analyzed the reports of the five largest grid operators, one may conclude that the vast majority of microinstallations connected to the grid are solar installations (Power... 2016). In addition to these, individual wind farms or small hydropower plants are mentioned in the reports.

The total capacity installed in photovoltaic systems in Poland in 2016 was about 199 MW (Curkowski et al. ed. 2017). This value was determined on the basis of the URE data on the installed capacity in individual types of RES installations and estimates of the Institute for Renewable Energy. According to the URE, the installed capacity in photovoltaics at the end of 2016 amounted to $99 \mathrm{MW}$, which is made up of the capacity of the installations that obtained the license for electrical energy production, installations were entered into the register of energy producers in a small installation, and micro-installations applying for issuing certificates of origin. The remaining $100 \mathrm{MW}$ is the capacity installed in photovoltaic micro-installations, which have been connected to the grid, but do not use the green certificate system (Curkowski et al. ed. 2017).

The above-mentioned photovoltaic micro-installations, which at the end of 2016 amounted to around 16 thousand, belong mostly to individuals and entrepreneurs. The number of photovoltaic microinstallations, which at the end of 2016 were held by prosumers, amounted to around 15 thousand, and their power was over $70 \mathrm{MW}$. At the same time, entrepreneurs own about 0.5 thousand micro-installations with a total capacity of about 20MW. According to IEO data, prosumers are mainly in possession of installations with low capacity $-90 \%$ of all photovoltaic micro installations, which belong to them, have a capacity of up to $10 \mathrm{~kW}$. Entrepreneurs invest mainly in photovoltaic installations with higher capacities - more than $60 \%$ of their micro-installations have power above $10 \mathrm{~kW}$. It should be noted at this point that prosumers and entrepreneurs investing in micro-installations contribute to the increase in installed capacity in photovoltaic installations in Poland. This may be justified by the fact that in only 2016, according to the Institute of Renewable Energy data, the power of photovoltaic micro-installations built in our country amounted to $73 \mathrm{MW}$.

Micro-scale wind turbines do not enjoy much interest on the part of prosumers. This is due to several factors. The first are high investment outlays in comparison with the photovoltaic micro-installations most popular among prosumers. The second are the issues connected with the need to select the right location for a wind farm. Although restrictive requirements with regard to the distance from residential buildings, which were introduced by the Act of May 20, 2016 on investments in wind farms, do not apply to micro-installations, however, it should be noted that wind conditions in the territory of Poland vary both on regional and local levels (Journal of Laws, item 961). Another problem is the need to apply for building permits in some cases. In a situation in which the wind turbine will permanently be connected with the ground by placing it on the foundation, it is treated as a building or a building structure and pursuant to Article 28(1) of the Building Law, one should apply for such permit (Journal of Laws, item 414, as amended). This is not necessary if a wind turbine is installed on the building. In the event that 
its height does not exceed $3 \mathrm{~m}$, such an action does not even require notification to the technical and construction administration authority, as provided for in Article 30(1)(3)(b) of the Building Law (Journal of Laws, item 414, as amended). There are several reasons for the low interest of potential prosumers in investments in small hydro power plants. Firstly, they are deterred by high investment expenditures. According to the Society for the Development of Small Hydropower Plants, the cost of the construction of a small hydro power plant with a capacity of $20 \mathrm{~kW}$ is about PLN 500 thousand, while the cost of a photovoltaic system with the same capacity may be up to five times lower (The Act... 2013). The second reason is the complicated formal and legal path associated with the construction of a small hydro power plant. Pursuant to $\S 3(1)(5)$ of the Regulation of the Council of Ministers of November 9, 2010, hydroelectric power plants are classified as projects that may significantly affect the environment (Journal of Laws No 213, item 1397). In connection with the above, the investor is obliged to obtain the so-called environmental decision. In addition, he is forced to apply for: a decision on building conditions, a water permit, a decision on the acquisition of rights to use real property owned by the State Treasury, and a building permit. It should be noted that the construction of micro-installations using water energy requires going through the same procedure for obtaining permits and decisions of public administration, such as the construction of a hydro power plant with a capacity of several megawatts. Significant difficulties result also from the low hydropower potential of Poland, which is a consequence of, among others, precipitation that remains uneven over time and is low, as well as the specific shape of the surface, consisting in the dominance of lowland areas with small differences in ground levels (Stryczewska ed. 2012).

\section{Summary}

As a result of the considerations in the article on legal regulations governing prosumer energy in Poland, existing prosumer support mechanisms, and the presented data on the number of prosumers and the energy technologies used by them, the following conclusions can be drawn with regard to the prospects for the development of prosumer energy in Poland:

1. Prosumer energy is one of the answers to the need to increase the share of renewable energy in final energy consumption, which results from obligations of Poland being an EU member state. The Polish authorities, striving to fulfill these obligations, will be forced to take wider and more intensive actions for the development of not only RES, but also the prosumer energy model.

2. The introduction of the Act on RES resulted in a significant increase in the number of prosumers in the years 2015 and 2016. This is mainly due to the legal regulation of the energy sector employing renewable sources, but also the introduction of a number of administrative and legal streamlining for microinstallation owners.

3. The development of prosumer energy in Poland is also supported by the Prosumer funding program and umbrella programs. These programs reduce the investment costs of unwaveringly 
expensive energy technologies using RES, which remain a significant obstacle for many potential prosumers.

4. The Act on RES narrows the understanding of the notion of a prosumer and includes support only for electrical energy producers. Meanwhile, the prosumer, understood more broadly, is oftentimes also a producer of heat. Therefore, one should look into the justifiability of granting support for combined heat and power generators in micro-installations, which could contribute to the increase in the use of energy technologies such as micro-biogas plants with cogeneration units or ORC-based micro-scale heat and power plants.

5. Administrative and legal streamlining practices included in the Act on RES concern only micro-installations. Therefore, the comment of other researchers on this subject as to the need to extend such practices to high-efficiency low-emission installations, e.g. micro-scale power and heat plants powered by natural gas or LPG, seems quite accurate.

6. Some provisions of the current version of the Act on RES contradict the idea of prosumer energy. The Act in question lost its pro-social character once the amendment to the Act on RES of June 22, 2016 was introduced, as it prevented prosumers from selling unused electrical energy.

7. The number of prosumers in Poland is systematically growing, which is borne out by the data of the Polish Society of Transmission and Distribution of Electrical energy. This results not only from the support from the state, which the authors of this paper find somewhat insufficient (as evidenced by significant differences in the number of prosumers in Poland and Germany), but also from the growing ecological awareness of Poles and their entrepreneurship, the aim of which is to reduce costs energy.

8. In order to increase the interest of prosumers in other energy technologies in addition to the most popular photovoltaic technologies, specific administrative streamlining practices related to the creation of such installations should be introduced. In the case of the construction of micro -hydroelectric plants, meeting the requirements included in the definition of micro-installations, the formal and legal path of obtaining the necessary permits should be significantly reduced. One should pay attention to the fact that the potential of small hydropower industry in Poland is not used sufficiently. The result of the RESTOR Hydro project was the identification of 6,000 possible MEW locations in Poland, most of which are micro-installations, while the current number of MEW in our country is only 750 according to the Polish Association for Small Hydropower Development.

The article was implemented as part of statutory work No. 11.11.210.376. 


\section{References}

Act of December 29, 2015 amending the act on renewable energy sources and the Energy Law. L.J. of 2015, item 2365 (Ustawa z 29 grudnia 2015 r. o zmianie ustawy o odnawialnych źródłach energii oraz ustawy Prawo Energetyczne. Dz.U. z 2015, poz. 2365) (in Polish).

Act of June 22, 2016 amending the act on renewable energy sources and certain other acts. L.J. of 2016, item 925 (Ustawa z dnia 22 czerwca 2016 r. o zmianie ustawy o odnawialnych źródłach energii oraz niektórych innych ustaw. Dz.U. z 2016, poz. 925) (in Polish).

BŁAŻEJOWSKA, M. 2015. Development of prosumer energy in the light of the new Act on renewable energy sources (Rozwój energetyki prosumenckiej w świetle nowej Ustawy o odnawialnych źródłach energii) Roczniki Naukowe Stowarzyszenia Ekonomistów Rolnictwa i Agrobiznesu vol. 17, iss. 6, pp. 38-43 (in Polish).

BAJCZUK, R. 2014. Renewable energy sources in Germany - current state of development, interest groups and challenges (Odnawialne źródła energii w Niemczech - obecny stan rozwoju, grupy interesu $i$ wyzwania). Ed. Marek Karp Center for Eastern Studies, Warsaw (in Polish).

Bukowski et al. 2014 - BUKOWSKI, M., PANKowIEC, A., SZCZERBA, P. and ŚNIEGOCKI, A. ed. 2014 - Groundbreaking prosumer energy (Przełomowa energetyka prosumencka). Warsaw Institute for Economic Studies, Warsaw (in Polish).

BuRChARD-DZIUBINSKA, M. 2015. Prosumer on the energy market in Poland - an attempt to evaluate in the light of the theory of transaction costs (Prosument na rynku energii w Polsce - próba oceny w świetle teorii kosztów transakcyjnych). Economy in practice and theory vol. 41, iss. 4, pp. 5-19 (in Polish).

Communication from the Commission to The European Parliament, The Council, The European Economic and Social Committee and The Committee of The Regions. A policy framework for climate and energy in the period from 2020 to 2030, COM/2014/015.

CURKowsKi et al. 2017 - CURKowski, A., WIĘCKA, A. and ZARZECZNA, J. ed. 2017. Photovoltaic market in Poland (Rynek fotowoltaiki w Polsce). Institute for Renewable Energy, Warsaw, p. 35.

Directive 2009/28/EC of the European Parliament and of the Council of 23 April 2009 on the promotion of the use of energy from renewable sources. EU LJ 140/16.

Eurostat. Dowloaded from: [Online] http://ec.europa.eu/eurostat/statistics-explained/images/b/b7/Table_2Share_of_energy_from_renewable_sources_in_gross_final_consumption_of_energy_2004-2016.png [Access: 2018-03-05].

PN-EN 50438: 2010: Requirements for parallel connection of microgenerators to public low-voltage distribution grids (Wymagania dotyczące równoległego przyłaczania mikrogeneratorów do publicznych sieci rozdzielczych niskiego napięcia) (in Polish).

POPCZYK, J. 2014. Prosumer energy and its place in the energy sector (Energetyka prosumencka i jej miejsce w energetyce). Czysta Energia vol. 5, iss.1, pp. 20-24 (in Polish).

Power... 2015. Power transmission and distribution report for 2015 (Energetyka przesyłowa i dystrybucyjna raport za 2015 rok). The Polish Society for Transmission and Distribution of Electricity, Poznań, p. 47 (in Polish)

Power... 2016. Power transmission and distribution report for 2016 (Energetyka przesyłowa i dystrybucyjna raport za 2016 rok). Polish Society for Transmission and Distribution of Electricity, Poznań, p. 29 (in Polish)

Priority Program, SYSTEM - Support for environmental protection and water management activities carried out by external partners (Program Priorytetowy, SYSTEM - Wsparcie działań ochrony środowiska i gospodarki wodnej realizowanych przez partnerów zewnętrznych). Dowloaded from: [Online] https:// www.nfosigw.gov.pl/oferta-finansowania/srodki-krajowe/programy-priorytetowe/prosument-dofinansowanie-mikroinstalacji-oze/informacje-o-programie/ [Access: 2018-03-04] (in Polish) 
RĄCZKA et al. 2012 - RĄCZKA, J., SWORA, M. and STAWIANY, W. ed. 2012. Generation dispersed in modern energy policy (selected problems and challenges) (Generacja rozproszona w nowoczesnej polityce energetycznej (wybrane problemy i wyzwania)). National Fund for Environmental Protection and Water Management, Warsaw (in Polish).

Regional Operational Program of the Podkarpackie Province - Information on umbrella projects (Regionalny Program Operacyjny Województwa Podkarpackiego - Informacja dotyczaca projektów parasolowych). Dowloaded from: [Online] http://www.rpo.podkarpackie.pl/index.php/op-iii-czysta-energia/ 862-informacja-dotyczaca-projektow-parasolowych [Access: 2018-03-04] (in Polish).

Regulation of the Council of Ministers of 9 November 2010 on projects that may significantly affect the environment. Dz.U. No. 213 item 1397 (Rozporzadzenie Rady Ministrów z dnia 9 listopada 2010 r. w sprawie przedsięwzięć mogących znaczaco oddziaływać na środowisko. Dz.U. Nr 213, poz. 1397) (in Polish).

SŁUPIK, S. 2014. Prosumer energy and its impact on the electricity market (Energetyka prosumencka i jej wplyw na rynek energii elektrycznej). Studies and works of the faculty of economic sciences and management at the University of Szczecin vol. 2, p. 37, pp. 127-136 (in Polish).

STRYCZEWSKA, H.D. ed. 2012. Renewable energies - an overview of application technologies (Energie odnawialne - przeglad technologii zastosowań). Lublin University of Technology, Lublin, p. 161 (in Polish).

The Act of July 7, 1994 Construction Law. Unified text L.J. of 1994, item 414 as amended (Ustawa z dnia 7 lipca 1994 r. Prawo budowlane. Tekst jednolity Dz.U. z 1994, poz. 414 z późn. zm.) (in Polish).

The Act of April 10, 1997 Energy Law. Unified text from 1997, item 348 as amended (Ustawa z dnia 10 kwietnia 1997 r. Prawo energetyczne. Tekst jednolity Dz.U. z 1997, poz. 348 z późn. zm.) (in Polish)

The Act of February 20, 2015 on renewable energy sources. Unified text L.J. of 2015, item 478 as amended (Ustawa z 20 lutego 2015 r. o odnawialnych źródłach energii. Tekst jednolity Dz.U. z 2015, poz. 478 z późn. zm.) (in Polish).

The Act of May 202016 on investments in the field of wind farms. Dz.U. of 2016, item 961 (Ustawa z dnia 20 maja 2016 r. o inwestycjach w zakresie elektrowni wiatrowych. Dz.U. z 2016, poz. 961) (in Polish).

The RES Act in the light of the construction and operation of small hydropower plants - a document of the Society for the Development of Small Hydroelectric Power Plants (Ustawa o OZE w świetle budowy i eksploatacji matych elektrowni wodnych - dokument Towarzystwa Rozwoju Matych Elektrowni Wodnych). Downloaded from: http://trmew.pl/fileadmin/user_upload/current_version/trmew.pl/ strona_glowna/aktualnosci/2013/02/TRMEW_Ustawa_o_OZE.pdf [Access: 2018-03-07] (in Polish).

WiśNIEWSKI, G. 2015. The role of FiT in the development of prosumer energy (Rola FiT w rozwoju energetyki prosumenckiej). Czysta Energia vol. 8, iss. 2, pp. 22-26 (in Polish).

ŻMIJEWSKI, K. ed. 2013. Prosumer in intelligent power grid - report (Prosument w inteligentnej sieci energetycznej-raport). The Eugeniusz Kwiatkowski Institute, Warsaw, p. 33 (in Polish). 


\section{Charakterystyka rozwoju energetyki prosumenckiej w Polsce}

\section{Streszczenie}

Podstawowym celem artykułu była ocena stanu rozwoju energetyki prosumenckiej w Polsce. W rozdziale pierwszym omówiono podstawowe pojęcia związane z energetyką prosumencką (mikroinstalacja, prosument), które zostały zdefiniowane w Ustawie o odnawialnych źródłach energii z dnia 20 lutego 2015 r. (Dz.U. poz. 478 ze zm.) oraz odniesiono się do polityki energetycznej Unii Europejskiej w kontekście rozwoju prosumenckiego modelu energetyki. W tej części pracy wskazano liczne korzyści dla polskiej gospodarki oraz konsumentów energii elektrycznej wynikające z rozwoju prosumeryzmu w polskiej energetyce, ale również zwrócono uwagę na bariery, które nadal stoją na drodze rozwoju energetyki prosumenckiej w naszym kraju. W rozdziale drugim dokonano wykładni fundamentalnych przepisów ustawy o odnawialnych źródłach energii z dnia 20 lutego 2015 r. (Dz.U. poz. 478 ze zm.; dalej: ustawa o OZE). $\mathrm{Na}$ ich podstawie omówiono system upustów, będący obecnie stosowanym w polskim porządku prawnym system wsparcia prosumentów. Wskazano także liczne uproszczenia administracyjno-prawne wynikające z zapisów wspomnianej ustawy o OZE. Krytyczne podejście do ustawy o OZE pozwoliło na uwypuklenie niekorzystnych lub nieprecyzyjnych przepisów w kontekście rozwoju prosumenckiego modelu energetyki. W rozdziale trzecim opisano programy dofinansowania wspierające rozwój energetyki prosumenckiej w Polsce, poprzez partycypowanie w kosztach zakupu i montażu mikroinstalacji. Dane liczbowe charakteryzujące stan energetyki prosumenckiej w naszym kraju zawarto w rozdziale 4 . Na ich podstawie podjęto również próbę omówienia zależności pomiędzy liczbą prosumentów a udziałem energii elektrycznej z odnawialnych źródeł w całkowitej jej konsumpcji. W rozdziale piątym pochylono się nad technologiami energetycznymi wykorzystywanymi w energetyce prosumenckiej w Polsce. Wskazano w nim przyczyny dużej popularności paneli fotowoltaicznych wśród polskich prosumnetów, przy niskim zainteresowaniu mikroturbinami wiatrowymi i małymi elektrowniami wodnymi.

SŁOWA KLUCZOWE: energetyka prosumencka, energia odnawialna, ustawa o OZE 